九州大学学術情報リポジトリ

Kyushu University Institutional Repository

\title{
Regulation of Angiotensin II receptor signaling by cysteine modification of $\mathrm{NF}-\kappa \mathrm{B}$
}

Nishida, Motohiro

Department of Pharmacology and Toxicology, Graduate School of Pharmaceutical Sciences, Kyushu University

Kitajima, Naoyuki

Department of Pharmacology and Toxicology, Graduate School of Pharmaceutical Sciences, Kyushu University

Saiki, Shota

Department of Pharmacology and Toxicology, Graduate School of Pharmaceutical Sciences, Kyushu University

Nakaya, Michio

Department of Pharmacology and Toxicology, Graduate School of Pharmaceutical Sciences, Kyushu University

他

http://hdl. handle. net/2324/25612

出版情報：Nitric 0xide. 25 (2)，pp.112-117，2011-08-01. Elsevier バージョン:

権利関係: (C) 2010 Published by Elsevier Inc. 
Review Article

Regulation of Angiotensin II receptor signaling by cysteine modification of NF- $\kappa \mathrm{B}$

Motohiro Nishida, Naoyuki Kitajima, Shota Saiki, Michio Nakaya and Hitoshi Kurose

Department of Pharmacology and Toxicology, Graduate School of Pharmaceutical

Sciences, Kyushu University, 3-1-1 Maidashi, Higashi-ku, Fukuoka 812-8582, Japan

Corresponding authors:

Motohiro Nishida

Department of Pharmacology and Toxicology, Graduate School of Pharmaceutical

Sciences, Kyushu University, 3-1-1 Maidashi, Higashi-ku, Fukuoka 812-8582, Japan. TEL\&FAX: +81-92-642-6878

nishida@phar.kyushu-u.ac.jp

Hitoshi Kurose

Department of Pharmacology and Toxicology, Graduate School of Pharmaceutical Sciences, Kyushu University, 3-1-1 Maidashi, Higashi-ku, Fukuoka 812-8582, Japan. TEL\&FAX: +81-92-642-6884

kurose@phar.kyushu-u.ac.jp 


\begin{abstract}
Angiotensin II (Ang II) is a major vasoactive peptide of the renin-angiotensin system. Ang II is originally found as one of potent vasoconstrictors, but is now attracted attention as an essential mediator of many cardiovascular problems, including endothelial dysfunction, arrhythmia and structural remodeling of cardiovascular systems. Most of the known pathophysiological effects of Ang II are mediated through Ang type1 receptors $\left(\mathrm{AT}_{1} \mathrm{Rs}\right)$, and the up-regulation of $\mathrm{AT}_{1} \mathrm{Rs}$ is one of important causes by which Ang II can contribute to cardiovascular diseases. A growing body of evidence has suggested that reactive oxygen species (ROS) and reactive nitrogen species (RNS) play important roles in the regulation of $A_{1} R$ signaling. In cardiac fibroblasts, stimulation with cytokines or bacterial toxins induces $\mathrm{AT}_{1} \mathrm{R}$ up-regulation through NADPH oxidase-dependent ROS production. In contrast, nitric oxide $(\mathrm{NO})$ decreases $\mathrm{AT}_{1} \mathrm{R}$ density through cysteine modification (S-nitrosylation) of a transcriptional factor, nuclear factor $\kappa \mathrm{B}(\mathrm{NF}-\kappa \mathrm{B})$. The difference between the effects of ROS and NO on $\mathrm{AT}_{1} \mathrm{R}$ expression may be caused by the difference between intracellular location of ROS signaling and that of NO signaling, as the agonist-induced S-nitrosylation of $\mathrm{NF}-\kappa \mathrm{B}$ requires a local interaction between NO synthase (NOS) and NF- $\mathrm{BB}$ in the perinuclear region. Thus, the spatial and temporal regulation of cysteine modification by ROS or RNS may underlie the resultant changes of $\mathrm{AT}_{1} \mathrm{R}$ signaling induced by agonist stimulation.
\end{abstract}

Keywords: Angiotensin, $\mathrm{AT}_{1}$ receptor, heart, reactive oxygen species, nuclear factor- $\kappa \mathrm{B}, \mathrm{S}$-nitrosylation 


\section{Ang II signaling in the heart}

The renin-angiotensin system (RAS) plays an important role in maintaining blood pressure homeostasis and salt balance in mammals [1, 2]. Ang II, a key regulator of RAS and exerts biological functions [3, 4], is generated to the following pathway. The protease renin first cleaves angiotensinogen to generate Ang I, which is composed of 10 amino acid polypeptide (Ang (1-10)). Next, the Ang converting enzyme (ACE) cleaves Ang I to generate Ang II (Ang (1-8)). Although there exists alternative Ang II-generating enzymes, such as cathepsins and chymase [5, 6], ACE is believed to be the sole enzyme in the regulation of Ang II production in the RAS [1, 2]. Ang II is then degraded to the heptapeptide Ang (1-7) by ACE2 [7]. Several reports have shown a counter-regulatory role for Ang (1-7) by opposing many $\mathrm{AT}_{1} \mathrm{R}$-mediated actions $[8,9]$. The Ang (1-7) is further degraded by aminopeptidase to generate Ang III (Ang (2-8)) and Ang IV (Ang (3-8)). These Ang-derived metabolites exert biological activities through binding to $G$ protein-coupled receptors (GPCRs) including $\mathrm{AT}_{1} \mathrm{R}, \mathrm{AT}_{2} \mathrm{R}$, and Mas [10, 11]. Among the Ang-derived metabolites, Ang II is a key regulator of cardiovascular functions, and most of biological effects of Ang II are mediated via $\mathrm{AT}_{1} \mathrm{R}$ $[3,4,10-12]$.

$\mathrm{AT}_{1} \mathrm{R}$-mediated signaling is divided into two groups: $\mathrm{G}$ protein-dependent and $\mathrm{G}$ protein-independent signaling pathways [13]. $\quad \mathrm{AT}_{1} \mathrm{Rs}$ are known to couple with three $\mathrm{G}$ protein subfamilies; $G_{q}, G_{i}, G_{12}[13,14]$. Among them, $G_{q}$ and $G_{12}$ family proteins-mediated signaling pathways participate in structural remodeling of the heart (Figure 1). The $\mathrm{G}_{\mathrm{q}}$ family protein induces activation of phospholipase $\mathrm{C}$ (PLC), which in turn induces increase in intracellular $\mathrm{Ca}^{2+}$ concentration $\left(\left[\mathrm{Ca}^{2+}\right]_{\mathrm{i}}\right)$ through production inositol-1,4,5-trisphosphate $\left(\mathrm{IP}_{3}\right)$ and diacylglycerol (DAG) by hydrolyzing 
phosphatidylinositol 4,5-bisphosphate $\left(\mathrm{PIP}_{2}\right)$. Sustained increase in $\left[\mathrm{Ca}^{2+}\right]_{\mathrm{i}}$ in cardiomyocytes induces activation of calmodulin $(\mathrm{CaM})$-dependent protein phosphatase $2 \mathrm{~B}$, calcineurin, which leads to increase in expression of hypertrophic genes, such as atrial natriuretic peptide (ANP), $\beta$-myosin heavy chain ( $\beta$-MHC), and $\alpha$-skeletal muscle actin ( $\alpha$-SKA), through activation of nuclear factor of activated T cells (NFAT) [15]. We have recently reported that DAG-activated transient receptor potential canonical (TRPC) channels (TRPC3 and TRPC6) mediate Ang II-induced $\mathrm{Ca}^{2+}$ influx through voltage-dependent $\mathrm{Ca}^{2+}$ channel (VDCC) and cardiac hypertrophy in vivo and in vitro $[16,17]$. In addition, activation of extracellular signal-regulated kinase (ERK) signaling pathway also participates in $\mathrm{G}_{\mathrm{q}}$-mediated cardiac hypertrophy. Lorenz et al. [18] has reported that $G \beta \gamma$ released from $G \alpha_{q}$ induces autophosphorylation of ERK1/2 at $\mathrm{Thr}^{188}$ residue and subsequent nuclear translocation of ERK1/2, resulting in inducing expression of hypertrophic genes. Ang II also induces ROS production through NADPH oxidase activation [19, 20]. Interestingly, Ang II-induced ROS production through Nox2 activation attenuates basal endothelial NOS (eNOS) activity through proline-rich tyrosine kinase (Pyk2)-dependent phosphorylation of eNOS at Tyr657 in endothelial cells [21], suggesting the mechanism of endothelial dysfunction observed in cardiovascular diseases associated with increased activity of the RAS. Using rat neonatal cardiomyocytes, we found that $\mathrm{G}_{12}$ family proteins mediate Ang II-induced ROS production and activation of c-Jun $\mathrm{NH}_{2}$-terminal kinase (JNK) and p38 MAPK [22, 23]. The activation of apoptosis signal-regulating kinase (ASK) and protein tyrosine kinase (PTK) by cysteine oxidation of thioredoxin and protein tyrosine phosphatase 1B may participate in ROS-mediated activation of JNK and p38MAPK [3, 4]. These results suggest that ROS function as a second messenger of $G_{12 / 13}$ signaling in 
cardiomyocytes. Furthermore, the inhibition of $\mathrm{G \alpha}_{12 / 13}$ signaling in cardiomyocytes attenuates pressure overload-induced collagen deposition of the heart (fibrosis), using transgenic mice with cardiomyocytes-specific overexpression of regulator of $\mathrm{G}$ protein signaling (RGS) domain of p115 Rho guanine nucleotide exchange factor (p115RhoGEF) [24]. These results suggest that $\mathrm{G \alpha}_{12 / 13}$-mediated ROS production contributes to cardiac fibrosis induced by pressure overload. As cardiac fibrosis is one of major causes of left ventricular diastolic dysfunction, and the inhibition of G $\alpha_{12 / 13}$-mediated ROS signaling attenuated diastolic dysfunction, $\mathrm{G} \alpha_{12 / 13}$-mediated ROS signaling may be a novel therapeutic target for the treatment of heart failure.

\section{Redox regulation of $\mathrm{AT}_{1} \mathrm{R}$ proteins}

Expression cloning from bovine adrenal and rat smooth muscle cells has revealed that both $\mathrm{AT}_{1} \mathrm{Rs}$ are typical seven transmembrane domain proteins, composed of 359 amino acids and a molecular mass of about $41 \mathrm{kDa}$ [25]. As the $\mathrm{AT}_{1} \mathrm{R}$ possesses three $\mathrm{N}$-glycosylation sites and four cysteine residues in the extracellular regions, the native glycosylated $\mathrm{AT}_{1} \mathrm{R}$ has a molecular mass of about $65 \mathrm{kDa}[26]$. Although the rodent $\mathrm{AT}_{1} \mathrm{Rs}$ exist as two distinct subtypes, $\mathrm{AT}_{1 \mathrm{~A}} \mathrm{R}$ and $\mathrm{AT}_{1 \mathrm{~B}} \mathrm{R}$, that are $95 \%$ identical in their amino acid sequences, these structural features are present in several other mammalian and nonmammalian $\mathrm{AT}_{1} \mathrm{Rs}[10,27]$. The $\mathrm{AT}_{1} \mathrm{Rs}$ are not only activated by Ang-derived metabolites, but also activated by mechanical stretch [28, 29]. The disulfide bridges between the N-terminal region and third extracellular loop, and between the first and second extracellular loops are formed to maintain the conformation of the $\mathrm{AT}_{1} \mathrm{R}$ protein [30]. As the disulfide bridge between the N-terminal region and third extracellular loop is not present in $\mathrm{AT}_{2} \mathrm{R}$, the $\mathrm{AT}_{2} \mathrm{R}$ is resistant to inactivation by reducing agents. 
Furthermore, Zhang et al. [31] has recently reported that nitro-oleic acid specifically binds to the $\mathrm{AT}_{1} \mathrm{R}$, reduces $\mathrm{G}_{\mathrm{q}}$ protein coupling, and inhibits inositol-1,4,5-trisphosphate production and $\mathrm{Ca}^{2+}$ mobilization, without inhibiting Ang II binding to the receptor. Thus, the $\mathrm{AT}_{1} \mathrm{R}$-mediated signaling is negatively regulated by the oxidation or reduction of the $\mathrm{AT}_{1} \mathrm{Rs}$.

\section{Regulation of $\mathrm{AT}_{1} \mathrm{R}$ expression level}

The gene expression of $\mathrm{AT}_{1} \mathrm{R}$ is regulated by various transcriptional factors, such as Sp1, Sp3, myocyte enhancing factor (MEF)-2, peroxisome proliferator-activated receptor (PPAR)- $\gamma$, and $\mathrm{NF}-\kappa \mathrm{B}$ [32-36]. It has been reported that $\mathrm{Sp} 1$ and $\mathrm{Sp} 3$ are predominantly responsible for regulating the basal expression of the human $\mathrm{AT}_{1} \mathrm{R}$ gene $[33,37]$ In contrast, MEF-2 heterodimers and Sp1 are required for basal expression of the rat $\mathrm{AT}_{1 \mathrm{~A}} \mathrm{R}$ gene [34]. PPAR- $\gamma$, an anti-inflammatory transcriptional factor, and Sp1 directly interact with each other on a CG-box-related sequence within the -58/-34 bp region of the rat $A T_{1 A} R$ promoter, which leads to suppression of $A_{1 A} R$ transcription by inhibiting Sp1 binding activity [32]. On the other hand, NF- $\kappa \mathrm{B}$, an inflammatory transcriptional factor, has been reported to participate in up-regulation of rat $\mathrm{AT}_{1 \mathrm{~A}} \mathrm{R}$ density induced by proinflammatory cytokines [36, 38, 39]. Cowling et al. [36] has reported that NF- $\kappa \mathrm{B}$ binds 2 cis-reponse elements located at $-365 /-355$ bp and $-2540 /-2530 \mathrm{bp}$ and induce transactivation of a minimal promoter. They have indicated that proinflammatory cytokines, such as tumor necrosis factor- $\alpha$ (TNF- $\alpha$ ) and interleukin-1 $\beta$ (IL-1 $\beta$ ), increase the expression level of $\mathrm{AT}_{1 \mathrm{~A}} \mathrm{R}$ (Figure 2). Transcription of the rat $\mathrm{AT}_{1 \mathrm{~A}} \mathrm{R}$ is also enhanced by Toll-like receptor 4 (TLR4) ligands, such as lipopolysaccharide (LPS) and oxidized low-density lipoprotein (LDL), both of 
which strongly increase NF- $\kappa \mathrm{B}$ activity. In contrast, NO, growth factors, statins and 15-deoxy- $\delta$-PGJ $J_{2}$ decrease $\mathrm{AT}_{1} \mathrm{R}$ density $[32,40-43]$. This mechanism may be explained by the decrease in DNA binding affinity of transcriptional factors through oxidative modification [43]. In addition, Ang II, cAMP stimulating agents and estrogens increase $\mathrm{AT}_{1} \mathrm{R}$ mRNA decay rates, leading to decrease in $\mathrm{AT}_{1} \mathrm{R}$ density (Figure 2). The $\mathrm{AT}_{1} \mathrm{R}$ mRNA stability is regulated by calreticulin. The phosphorylated calreticulin binds to AUUUUA sequence localized in 3'-UTR region of $\mathrm{AT}_{1} \mathrm{R}$ mRNA, leading to increase in $\mathrm{AT}_{1} \mathrm{R}$ mRNA stability [44]. Thus, both transcriptional and posttranscriptional mechanisms are involved in the regulation of $\mathrm{AT}_{1} \mathrm{R}$ expression.

\section{ROS-mediated up-regulation of $\mathrm{AT}_{1} \mathrm{Rs}$}

Ichiki et al. [45] have previously reported that exogenous exposure of hydrogen peroxide $\left(\mathrm{H}_{2} \mathrm{O}_{2}\right)$ decreases $\mathrm{AT}_{1} \mathrm{R}$ density through $\mathrm{AT}_{1} \mathrm{R}$ mRNA destabilization. As the Ang II-induced decrease in $\mathrm{AT}_{1} \mathrm{R}$ mRNA stability was diminished by the treatment with diphenyleneiodonium (DPI), an NADPH oxidase inhibitor, they suggest that endogenous ROS derived from NADPH oxidase negatively regulate $\mathrm{AT}_{1} \mathrm{R}$ mRNA stability. In contrast, treatment with IL-1 $\beta$ and TNF- $\alpha$ induces NADPH oxidase-dependent $\mathrm{ROS}$ production and increases $\mathrm{AT}_{1} \mathrm{R}$ density [38, 39, 46]. Therefore, the role of endogenous ROS in the regulation of $\mathrm{AT}_{1} \mathrm{R}$ expression may depend on the location and timing of ROS production induced by agonist stimulation.

We have recently found that endogenous $\mathrm{ROS}$ increase $\mathrm{AT}_{1} \mathrm{R}$ density in rat cardiac fibroblasts [47]. Pertussis toxin (PTX), a major virulence factor of Gram-negative bacillus Bordetella pertussis which causes whooping cough, is well established as a 
pharmacological tool for a specific inhibitor of receptor- $\mathrm{G}_{\mathrm{i} / \mathrm{o}}$ protein coupling. PTX is composed of A-protomer and B-oligomer, and A-protomer exerts ADP-ribosyltransferase activity on the $\alpha$-subunit of heterotrimeric $G_{i}$ proteins $\left(G \alpha_{i}\right)$, leading to inhibition of receptor-G protein coupling, whereas B-oligomer of PTX recognizes and binds carbohydrate-containing receptors that deriver A-protomer into the cytosol. As the treatment of rat cardiac fibroblasts with PTX induces up-regulation of $\mathrm{AT}_{1} \mathrm{Rs}$, indicating that PTX increases $\mathrm{AT}_{1} \mathrm{R}$ density independently of ADP ribosylation. We also found that PTX induces TLR4 stimulation, which leads to activation of a small GTP-binding protein, Rac, through Syk tyrosine kinase (Figure 3). Activation of Rac subsequently induces NF- $\kappa \mathrm{B}$ activation through $\mathrm{I} \kappa \mathrm{B} \alpha$ phosphorylation and degradation. Activation of NF- $\kappa \mathrm{B}$ then increases expression of IL-1 $\beta$, which in turn activates Rac through IL-1 $\beta$ receptor stimulation. Thus, IL-1 $\beta$-dependent amplification of ROS-mediated NF- $\kappa \mathrm{B}$ signaling is required for the PTX-induced $\mathrm{AT}_{1} \mathrm{R}$ up-regulation. It is still unclear how endogenous ROS induce phosphorylation and degradation of $\mathrm{I} \kappa \mathrm{B} \alpha$, but recent studies have suggested that stress-induced $\mathrm{Ca}^{2+}$ mobilization induces nuclear accumulation of $\mathrm{I} \kappa \mathrm{B} \alpha$, leading to $\mathrm{I} \kappa \mathrm{B} \alpha$ degradation without $\mathrm{N}$-terminal phosphorylation of $\mathrm{I} \kappa \mathrm{B} \alpha[48,49]$. As the stimulation of TLR4 induces ROS production independently of MyD88 signaling pathways has also been reported in macrophages [50], ROS-mediated signaling induced by TLR4 stimulation may play a critical role in TLR4-induced inflammatory responses (i.e., $\mathrm{AT}_{1} \mathrm{R}$ up-regulation) in mammalian cells.

5. Suppression of $\mathrm{AT}_{1} \mathrm{R}$ signaling by $\mathrm{S}$-nitrosylation

It has been reported that NO and nitro-unsaturated fatty acids decrease Ang II 
signaling in the heart $[31,43]$. We have recently found that long-term treatment of rat neonatal cardiac fibroblasts with adenosine 5 '-triphosphate (ATP) decreases $\mathrm{AT}_{1} \mathrm{R}$ density. This phenomenon is so-called 'heterologous down-regulation', which indicates that stimulation of one GPCR reduces expression levels of different GPCR [51]. Cross-talk between different GPCR signaling pathways may serve to fine-tune cell signaling [52], but the molecular mechanism(s) underlying heterologous down-regulation is largely unknown. The ATP-induced $\mathrm{AT}_{1} \mathrm{R}$ down-regulation was canceled by the treatment with cyclosporine A or siRNAs for $\mathrm{P} 2 \mathrm{Y}_{2} \mathrm{R}$, indicating that $\mathrm{P} 2 \mathrm{Y}_{2} \mathrm{R}$-stimulated sustained increase in intracellular $\mathrm{Ca}^{2+}$ concentration and subsequent activation of calcineurin-NFAT signaling participate in ATP-induced $\mathrm{AT}_{1} \mathrm{R}$ down-regulation. Interestingly, the ATP-induced suppression of $\mathrm{AT}_{1} \mathrm{R}$ signaling was completely diminished by $1400 \mathrm{~W}$, a selective inhibitor of inducible NO synthase (iNOS). As iNOS promoter region contains some NFAT-binding sequences and activation of calcineurin-NFAT signaling pathway has been reported to induce expression of iNOS proteins in cardiomyocytes and in vivo mouse hearts [53]. In fact, ATP increased expression of iNOS proteins in a concentration-dependent manner, and ATP-induced iNOS expression was completely suppressed by cyclosporine A. The expression of constitutively active mutant of NFAT also decreased $\mathrm{AT}_{1} \mathrm{R}$ density, which was canceled by $1400 \mathrm{~W}$. Thus, NFAT-dependent iNOS expression is required for ATP-induced suppression of $\mathrm{AT}_{1} \mathrm{R}$ signaling. We focused on the conserved cysteine (Cys) residue in the Rel homology domain of NF-kB [54, 55]. The Cys wedged between acidic and basic amino acids is nucleophilic, acidic and redox active, and numerous reactions may occur on this Cys thiol side chain [56]. As the reactive Cys locates in the Rel homology domain that is involved in DNA binding or dimer 
formation of $\mathrm{p} 65$, the NO-mediated Cys modification (S-nitrosylation) of p65 may decrease transcriptional activity of NF- $\mathrm{BB}[54,55]$. Using biotin-switch assay method as shown in Fig. 4A, we found that treatment of rat cardiac fibroblasts with ATP for 24 hours actually induced S-nitrosylation of p65 subunit at Cys38. The promoter region of iNOS does not only contain NF- $\kappa \mathrm{B}$ binding sequences but also NFAT binding sequences (Fig. 4B). Treatment of cardiac fibroblasts with ATP induced iNOS expression, and the iNOS protein and p65 subunit were co-localized around the perinuclear regions (Fig. 4C). Immunoprecipitation study has revealed that ATP-induced iNOS forms a complex with p65. In contrast, treatment with IL-1 $\beta$ strongly increased expression of iNOS protein but did not induce the interaction of iNOS with p65, because IL-1 $\beta$ induces translocation of p65 from cytosol to the nucleus. We also found that flavin-binding domain of iNOS protein is a hot-spot in iNOS for the interaction with p65, and overexpression of iNOS fragment including flavin-binding domain completely suppressed the ATP-induced suppression of $\mathrm{AT}_{1} \mathrm{R}$ signaling. Thus, the formation of signaling complex between iNOS and p65 around the perinuclear region may be essential for the ATP-induced $\mathrm{AT}_{1} \mathrm{R}$ down-regulation.

\section{Conclusion}

Numerous studies have demonstrated that Cys modification by ROS and NO play important roles in agonist-induced signal transduction. Indeed, numerous proteins have been reported to be a target of NO [57]. We found that ROS and NO play important roles in the regulation of $\mathrm{AT}_{1} \mathrm{R}$ gene expression. ROS increases $\mathrm{AT}_{1} \mathrm{R}$ density through $\mathrm{I} \kappa \mathrm{B} \alpha$ degradation-dependent activation of $\mathrm{NF}-\kappa \mathrm{B}$, while NO decreases $\mathrm{AT}_{1} \mathrm{R}$ density through direct $\mathrm{S}$-nitrosylation of $\mathrm{NF}-\kappa \mathrm{B}$ p65 subunit. As the physical 
interaction between $\mathrm{p} 65$ and iNOS proteins are required for agonist-induced S-nitrosylation of $\mathrm{p} 65$, the location and the timing of ROS or NO production induced by agonist stimulation may be critical for the resultant regulation of $\mathrm{AT}_{1} \mathrm{R}$ signaling. Identification of the target protein that induces $I \kappa \mathrm{B} \alpha$ phosphorylation will be required for the understanding of the ROS-mediated signaling complex participating in $\mathrm{AT}_{1} \mathrm{R}$ up-regulation. A growing body of evidence has suggested that ROS and NO work as second messengers in cellular signaling, and the emergence of Cys modification (thiol oxidation and S-nitrosylation) by ROS and RNS may presage a new era in cardiovascular biology. Unraveling the regulation of Ang II signaling by Cys modification will achieve new therapeutic targets with great potential to improve clinical outcomes. 
References

[1] L.T. Skeggs, F.E. Dorer, M. Levine, K.E. Lentz, J.R. Kahn, The biochemistry of the renin-angiotensin system, Adv. Exp. Med. Biol. 130 (1980) 1-27.

[2] A.J. Turner, N.M. Hooper, The angiotensin-converting enzyme gene family: genomics and pharmacology, Tends. Pharmacol. Sci. 23 (2002) 177-183.

[3] Y. Saito, B.C. Berk, Angiotensin II-mediated signal transduction pathways, Curr. Hypertens. Rep. 4 (2002) L167-L171.

[4] R.M. Touyz, Reactive oxygen species as mediators of calcium signaling by Angiotensin II: implications in vascular physiology and pathophysiology, Antioxid. Redox Signaling. 7 (2005) 1302-1314.

[5] L.A. Belova, Angiotensin II-generating enzymes, Biochemistry (Mosc). 65 (2000) $1337-1345$.

[6] M. Miyazaki, S. Takai, Tissue Angiotensin II generating system by angiotensin-converting enzyme and chymase, J. Pharmacol. Sci. 100 (2006) 391-397.

[7] S.R. Tipnis, N.M. Hooper, R. Hyde, E. Karran, G. Christie, A.J. Turner, A human homolog of angiotensin-converting enzyme. Cloning and functional expression as a captopril-insensitive carboxypeptidase, J. Biol. Chem. 275 (2000) 33238-33243.

[8] R.A. Santos, F. Frezard, A.J. Ferreira, Angiotensin-(1-7): blood, heart, and blood vessels, Curr. Med. Chem. Cardiovas. Hematol. Agents. 3 (2005) 383-391.

[9] C.M. Ferrario, Angiotensin-converting enzyme 2 and angiotensin-(1-7): an evolving story in cardiovascular regulation, Hypertension 47 (2006) 515-521.

[10] M. de Gasparo, K.J. Catt, T. Inagami, J.W. Wright, Th. Unger, International union of pharmacology. XXIII. The angiotensin II receptors, Pharmacol. Rev. 52 (2000) 
415-472.

[11] C. Oro, H. Qian, W.G. Thomas, Type 1 angiotensin receptor pharmacology: signaling beyond G proteins, Pharmacol. Ther. 113 (2007) 210-226.

[12] G.H. Gibbons, V.J. Dzau, The emerging concept of vascular remodeling, N. Eng. J. Med. 330 (1994) 1431-1438.

[13] L. Hunyady, K.J. Catt, Pleiotropic AT1 receptor signaling pathways mediating physiological and pathogenic actions of Angiotensin II, Mol. Endocrinol. 20 (2006) 953-970.

[14] J. Sadoshima, S. Izumo, The cellular and molecular response of cardiac myocytes to mechanical stress, Annu. Rev. Physiol. 59 (1997) 551-571.

[15] J. Heineke, J.D. Molkentin, Regulation of cardiac hypertrophy by intracellular signaling pathways, Nat. Rev. Mol. Cell. Biol. 7 (2006) 589-600.

[16] N. Onohara, M. Nishida, R. Inoue, H. Kobayashi, H. Sumimoto, Y. Sato, Y. Mori, T. Nagao, H. Kurose, TRPC3 and TRPC6 are essential for angiotensin II-induced cardiac hypertrophy, EMBO J. 25 (2006) 5305-5316.

[17] S. Kiyonaka, K. Kato, M. Nishida, K. Mio, T. Numaga, Y. Sawaguchi, T. Yoshida, M. Wakamori, E. Mori, T. Numata, M. Ishii, H. Takemoto, A. Ojida, K. Watanabe, A. Uemura, H. Kurose, T. Morii, T. Kobayashi, Y. Sato, C. Sato, I. Hamachi, Y. Mori, Selective and direct inhibition of TRPC3 channels underlies biological activities of a pyrazole compound, Proc. Natl. Acad. Sci. USA 106 (2009) 5400-5405.

[18] K. Lorenz, J.P. Schmitt, E.M. Schmitteckert, M.J. Lohse, A new type of ERK1/2 autophosphorylation causes cardiac hypertrophy, Nat. Med. 15 (2009) 75-83.

[19] S. Rajagopalan, S. Kurz, T. Munzel, M. Tarpey, B.A. Freeman, K.K. Griendling, D.G. Harrison, Angiotensin II-mediated hypertension in the rat increases vascular superoxide 
production via membrane NADH/NADPH oxidase activation. Contribution to alterations of vasomotor tone, J. Clin. Invest. 97 (1996) 1916-1923.

[20] M. Ushio-Fukai, R.W. Alexander, M. Akers, K.K. Griendling, p38 mitogen-activated protein kinase is a critical component of the redox-sensitive signaling pathways activated by angiotensin II, J. Biol. Chem. 273 (1998) 15022-15029.

[21] A.E. Loot, J.G. Schreiber, B. Fisslthaler, I. Fleming, Angiotensin II impairs endothelial function via tyrosine phosphorylation of the endothelial nitric oxide synthase, J. Exp. Med. 206 (2009) 2889-2896.

[22] M. Nishida, S. Tanabe, Y. Maruyama, S. Mangmool, K. Urayama, Y. Nagamatsu, S. Takagahara, J.H. Turner, T. Kozasa, H. Kobayashi, Y. Sato, T. Kawanishi, R. Inoue, T. Nagao, H. Kurose, Ga $\alpha_{12 / 13}$-and reactive oxygen species-dependent activation of c-Jun $\mathrm{NH}_{2}$-terminal kinase and p38 MAPK by angiotensin receptor stimulation in rat neonatal cardiomyocytes, J. Biol. Chem. 280 (2005) 18434-18441.

[23] T. Fujii, N. Onohara, Y. Maruyama, S. Tanabe, H. Kobayashi, M. Fukutomi, Y. Nagamatsu, N. Nishihara, R. Inoue, H. Sumimoto, F. Shibasaki, T. Nagao, M. Nishida, H. Kurose, $G \alpha_{12 / 13}$-mediated production of reactive oxygen species is critical for angiotensin receptor-induced NFAT activation in cardiac fibroblasts, J. Biol. Chem. 280 (2005) 23041-23047.

[24] M. Nishida, Y. Sato, A. Uemura,Y. Narita, H. Tozaki-Saitoh, M. Nakaya, T. Ide, T. Suzuki, K. Inoue, T. Nagao, H. Kurose, P2 $\mathrm{Y}_{6}$ Receptor-G $\alpha_{12 / 13}$ signaling in cardiomyocytes triggers pressure overload-induced cardiac fibrosis, EMBO J. 27 (2008) 3104-3115.

[25] K. Sasaki, Y. Yamano, S. Bardhan, N. Iwai, J.J. Murray, M. Hasegawa, Y. Matsuda, T. Inagami, Cloning and expression of a complementary DNA encoding a bovine adrenal 
angiotensin II type-1 receptor, Nature (Lond) 351 (1991) 230-233.

[26] S. Jayadev, R.D. Smith, G. Jagadeesh, A.J. Baukal, L. Hunyady, K.J. Catt, N-linked glycosylation is required for optimal $\mathrm{AT}_{1 \mathrm{a}}$ Angiotensin receptor expression in COS-7 cells. Endocrinology 140 (1999) 2010-2017.

[27] T.S. Elton, M.M. Martin, Angiotensin II type1 receptor gene regulation. Transcriptional and posttranscriptional mechanisms, Hypertension 49 (2007) 953-961.

[28] Y. Zou, H. Akazawa, Y. Qin, M. Sano, H. Takano, T. Minamino, N. Makita, K. Iwanaga, W. Zhu, S. Kudoh, H. Toko, K. Tamura, M. Kihara, T. Nagai, A. Fukamizu, S. Umemura, T. Iiri, T. Fujita, I. komuro, Mechanical stress activates angiotensin II type 1 receptor without the involvement of angiotensin II, Nat. Cell Biol. 6 (2004) 499-506.

[29] N. Yasuda, S. Miura, H. Akazawa, T. Tanaka, Y. Qin, Y. Kiya, S. Imaizumi, M. Fujino, K. Ito, Y. Zou, S. Fukuhara, S. Kunimoto, K. Fukuzaki, T. Sato, J. Ge, N. Mochizuki, H. Nakaya, K. Saku, I. Komuro, Conformational switch of angiotensin II type 1 receptor underlying mechanical stress-induced activation, EMBO Rep. 9 (2008) 179-186.

[30] K. Ohyama, Y. Yamano, T. Sano, Y. Nakagomi, T. Hamakubo, I. Morishima, T. Inagami, Disulfide bridges in extracellular domains of Angiotensin II receptor type IA, Regul. Pept. 57 (1995) 141-147.

[31] J. Zhang, L. Villacorta, L. Chang, Z. Fan, M. Hamblin, T. Zhu, C.S. Chen, M.P. Cole, F.J. Schopfer, C.X. Deng, M.T. Garcia-Barrio, Y-H. Feng, B.A. Freeman, Y.E. Chen, Nitro-oleic acid inhibits angiotensin II-induced hypertension, Circ. Res. 107 (2010) $540-548$.

[32] A. Sugawara, K. Takeuchi, A. Uruno, Y. Ikeda, S. Arima, M. Kudo, K. Sato, Y. Taniyama, S. Ito, Transcriptional suppression of type 1 angiotensin II receptor gene expression by peroxisome proliferators-activated receptor- $\gamma$ in vascular smooth muscle 
cells, Endocrinology 142 (2001) 3125-3134.

[33] X. Zhao, M.M. Martin, T.S. Elton, Basal level transcriptional regulation of the human angiotensin II type 1 receptor gene, Biochim. Biophys. Acta. 1494 (2000) 181-184.

[34] K.B. Beason, M.E. Steinhelper, T.S. Elton, An A/T-rich cis-element is essential for rat angiotensin II type 1A receptor transcription in vascular smooth muscle cells. Biochim. Biophys. Acta. 1444 (1999) 25-34.

[35] T. Kubo, N. Kinjyo, A. Ikezawa, T. Kambe, R. Fukumori, Sp1 decoy oligodeoxynucleotide decreases angiotensin receptor expression and blood pressure in spontaneously hypertensive rats. Brain Res. 992 (2003) 1-8.

[36] R.T. Cowling, D. Gurantz, J.F. Peng, W.H. Dillmann, B.H. Greenberg, Transcription factor NF- $\mathrm{NB}$ is necessary for up-regulation of type 1 angiotensin II receptor mRNA in rat cardiac fibroblasts treated with tumor necrosis factor- $\alpha$ or interleukin-1 $\beta$, J. Biol. Chem. 277 (2002) 5719-5724.

[37] M.M. Martin, X. Victor, X. Zhao, J.K. McDougall, T.S. Elton, Identification and characterization of functional angiotensin II type 1 receptors on immortalized human fetal aortic vascular smooth muscle cells, Mol. Cell. Endocrin. 183 (2001) 81-91.

[38] R.T. Cowling, X. Zhang, V.C. Reese, M. Iwata, D. Gurantz, W.H. Dillmann, B.H. Greenberg, Effects of cytokine treatment on angiotensin II type 1A receptor transcription and splicing in rat cardiac fibroblasts, Am. J. Physiol. 289 (2005) H1176-H1183.

[39] D. Gurantz, R.T. Cowling, J. Francisco, J. Villarreal, B.H. Greenberg, Tumor necrosis factor- $\alpha$ upregulates angiotensin II type 1 receptors on cardiac fibroblasts, Circ.Res. 89 (1999) 272-279.

[40] Y. Ikeda, K. Takeuchi, T. Kato, Y. Taniyama, K. Sato, N. Takahashi, A. Sugawara, S. 
Ito, Transcriptional suppression of rat angiotensin $\mathrm{AT}_{1 \mathrm{a}}$ receptor gene expression by interferon-gamma in vascular smooth muscle cells, Biochem. Biophys. Res. Commun. 262 (1999) 494-498.

[41] G. Nickening, T.J. Murphy, Down-regulation by growth factors of vascular smooth muscle angiotensin receptor gene expression, Mol. Pharmacol. 46 (1994) 653-659.

[42] S. Wassmann, U. Laufs, A.T. Baumer, K. Muller, C. Konkol, H. Sauer, M. Bohm, G. Nickenig, Inhibition of geranylgeranylation reduces angiotensin II-mediated free radical production in vascular smooth muscle cells: involvement of angiotensin AT1 receptor expression and Rac1 GTPase, Mol. Pharmacol. 59 (2001) 646-654.

[43] T. Ichiki, M. Usui, M. Kato, Y. Funakoshi, K. Ito, K. Egashira, A. Takeshita, Downregulation of angiotensin II type 1 receptor gene transcription by nitric oxide, Hypertension 31 (1998) 342-348.

[44] G. Nickenig, F. Michaelsen, C. Muller, A. Berger, T. Vogel, A. Sachinidis, H. Vetter, M. Bohm, Destabilization of $\mathrm{AT}_{1}$ receptor mRNA by calreticulin, Circ. Res. 90 (2002) 53-58.

[45] T. Ichiki, K. Takeda, T. Tokunou, Y. Funakoshi, K. Ito, N. Iino, A. Takeshita, Reactive oxygen species-mediated homologous downregulation of angiotensin II type 1 receptor mRNA by angiotensin II, Hypertension 37 (2001) 535-540.

[46] M. Sundaresan, Z.X. Yu, V.J. Ferrans, D.J. Sulciner, J.S. Gutkind, K. Irani, P.J. Goldschmidt-Clermont, T. Finkel, Regulation of reactive-oxygen-species generation in fibroblasts by Rac1, Biochem. J. 318 (1996) 379-382.

[47] M. Nishida, R. Suda, Y. Nagamatsu, S. Tanabe, N. Onohara, M. Nakaya, Y. Kanaho, T. Shibata, K. Uchida, H. Sumimoto, Y. Sato, H. Kurose, Pertussis toxin upregulates angiotensin type1 receptors through TLR4-mediated Rac activation, J. Biol. Chem. 285 
(2010) 15268-15277.

[48] Y. Lao, D.C. Chang, Mobilization of $\mathrm{Ca}^{2+}$ from endoplasmic reticulum to mitochondria plays a positive role in the early stage of UV- or TNFalpha-induced apoptosis, Biochem. Biophys. Res. Commun. 373 (2008) 42-47.

[49] Y. Tsuchiya, T. Asano, K. Nakayama, T. Kato Jr, M. Karin, H. Kamata, Nuclear IKK $\beta$ is an adaptor protein for $\mathrm{I} \kappa \mathrm{B} \alpha$ ubiquitination and degradation in UV-induced NF- $\kappa \mathrm{B}$ activation, Mol. Cell 39 (2010) 570-582.

[50] Y.S. Bae, J.H. Lee, S.H. Choi, S. Kim, F. Almazan, J.L. Witztum, Y.I. Miller, Macrophages generate reactive oxygen species in response to minimally oxidized low-density lipoprotein: toll-like receptor 4- and spleen tyrosine kinase-dependent activation of NADPH oxidase 2. Circ. Res. 104 (2009) 210-218.

[51] T.T. Chuang, L. lacovelli, M. Sallese, A. De Blasi, G protein-coupled receptors: heterologous regulation of homologous desensitization and its implications, Trends Pharmacol. Sci. 17 (1996) 416-421.

[52] Y. Cordeaux, S.J. Hill, Mechanisms of cross-talk between G-protein-coupled receptors, Neurosignals 11 (2002) 45-57.

[53] K. Obasanjo-Blackshire, R. Mesquita, R.I. Jabr, J.D. Molkentin, S.L. Hart, M.S. Marber, Y. Xia, R.J. Heads, Calcineurin regulates NFAT-dependent iNOS expression and protection of cardiomyocytes: co-operation with Src tyrosine kinase, Cardiovasc. Res. 71 (2006) 672-683.

[54] Z.T. Kelleher, A. Matsumoto, J.S. Stamler, H.E. Marshall, NOS2 regulation of NF- $\kappa B$ by S-nitrosylation of p65, J. Biol. Chem. 282 (2007) 30667-30672.

[55] H.E. Marshall, J.S. Stamler, Inhibition of NF-кB by S-nitrosylation, Biochemistry 40 (2001) 1688-1693. 
[56] J.S. Stamler, E.J. Toone, S.A. Lipton, N.J. Sucher, (S)NO signals: translocation, regulation, and a consensus motif, Neuron 18 (1997) 691-696.

[57] B. Lima, M.T. Forester, D.T. Hess, J.S. Stamler, S-nitroyslation in cardiovascular signaling, Circ. Res. 106 (2010) 633-646. 
Figure legends

Figure 1. $\mathrm{AT}_{1} \mathrm{R}$ signaling pathways in the heart. $\mathrm{ASK}$; apoptosis signal-regulating kinase, PTK; protein tyrosine kinase, VDCC; voltage-dependent $\mathrm{Ca}^{2+}$ channel.

Figure 2. Regulation of $\mathrm{AT}_{1} \mathrm{R}$ transcription and translation by various factors. PPAR; peroxisome proliferator-activated receptor, LDL; low-density lipoprotein.

Figure 3. Hypothetical mechanism of ROS-mediated $\mathrm{AT}_{1} \mathrm{R}$ up-regulation induced by Pertussis toxin in rat cardiac fibroblasts.

Figure 4. Mechanism of $\mathrm{AT}_{1} \mathrm{R}$ down-regulation induced by NO. (A) principle of biotin-switch assay. (B) Potential binding sites of transcriptional factors existed in iNOS promoter region. (C) Changes in localization of iNOS and p65 proteins induced by ATP and IL-1 $\beta$. Cardiac fibroblasts were treated with ATP $(100 \mu \mathrm{M})$ or IL-1 $(1$ $\mathrm{ng} / \mathrm{ml}$ ) for 24 hours. (D) Localization of p65 defines iNOS-dependent S-nitrosylation of p65 and resultant $\mathrm{AT}_{1} \mathrm{R}$ down-regulation. 
Angiotensin II

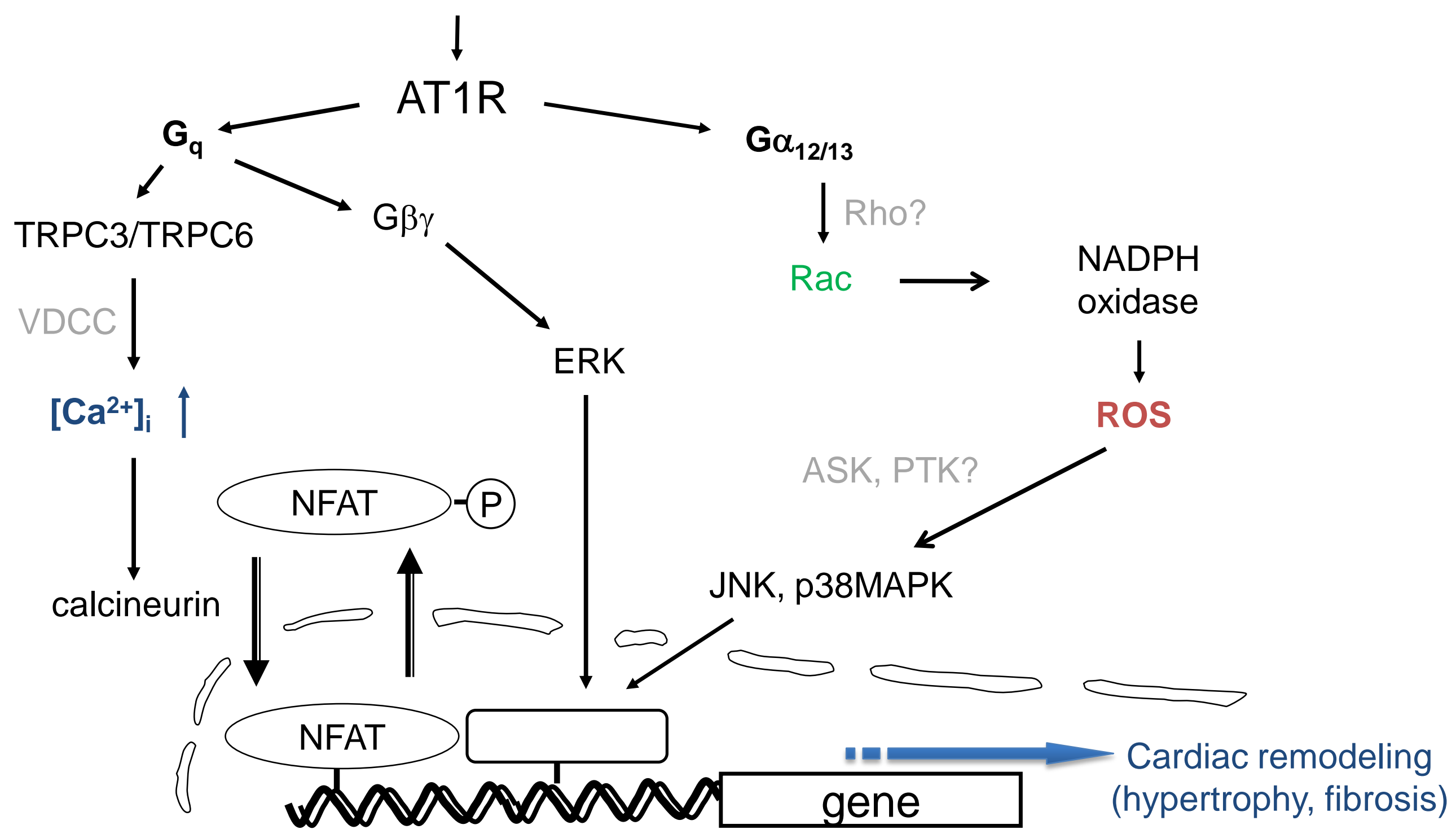

Figure 1. Nishida et al. 


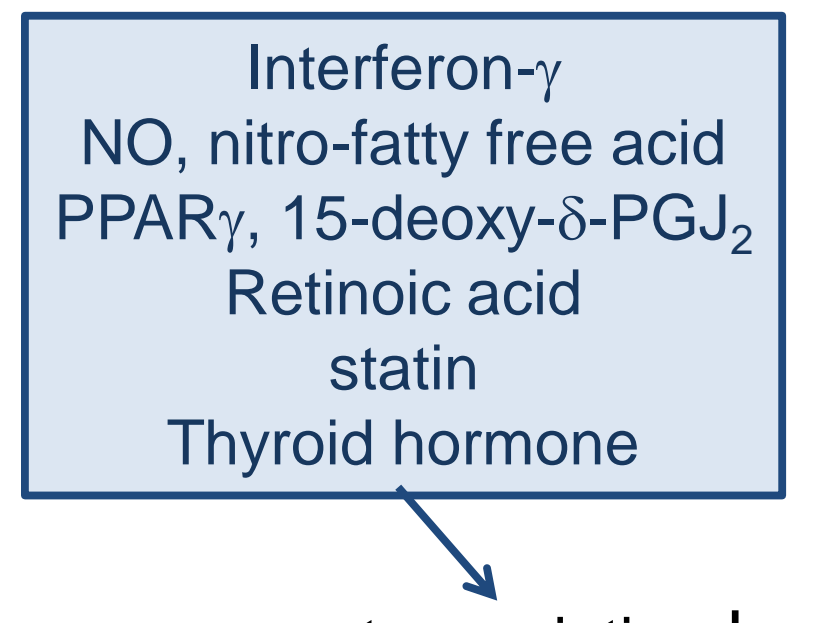

transcription $\downarrow$

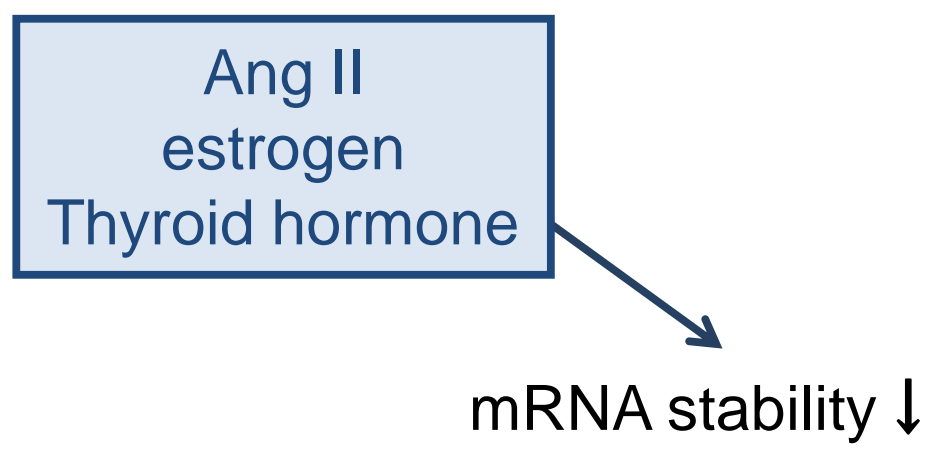

AT1R $\downarrow$
AT1R gene

avasaracan

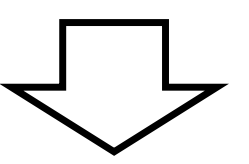

AT1R mRNA

MWM
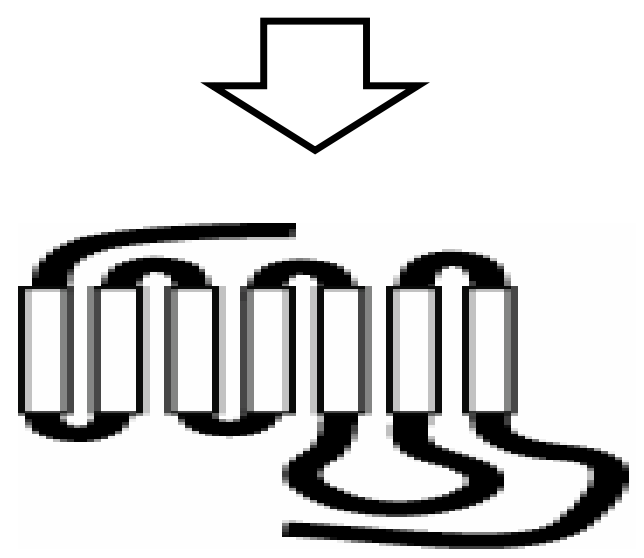

cytokine (TNF- $\alpha$, IL-1 $\beta$, IL-6)

TLR4 agonist (LPS, PTX)

Cyclosporine A

$C$ reactive protein

Growth hormone

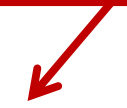

transcription $\uparrow$

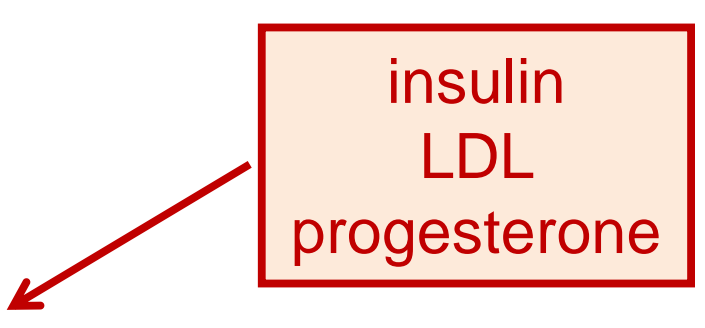

mRNA stability $\uparrow$

AT1R $\uparrow$

Figure 2. Nishida et al. 


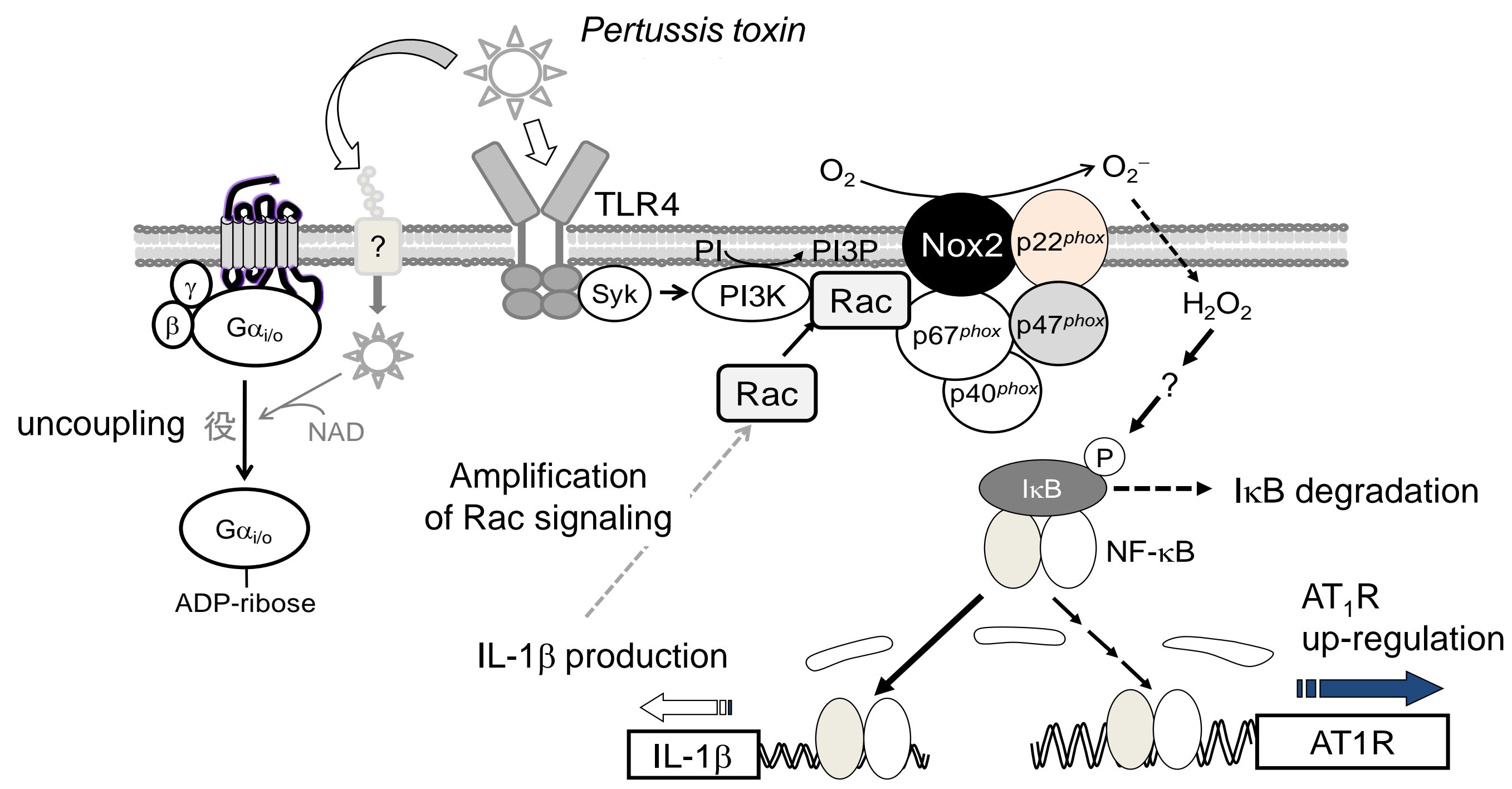

Figure 3. Nishida et al. 
A

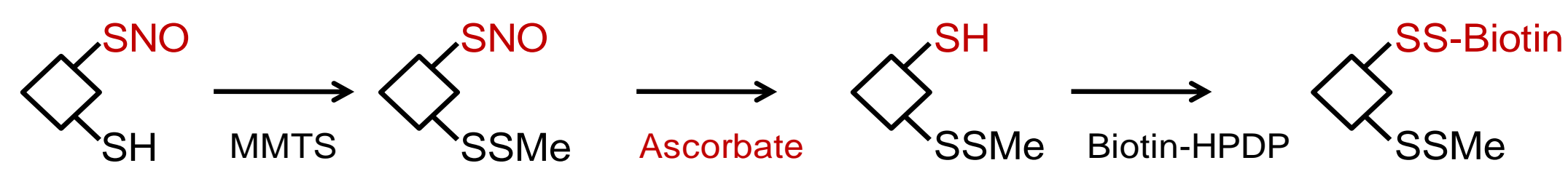

B

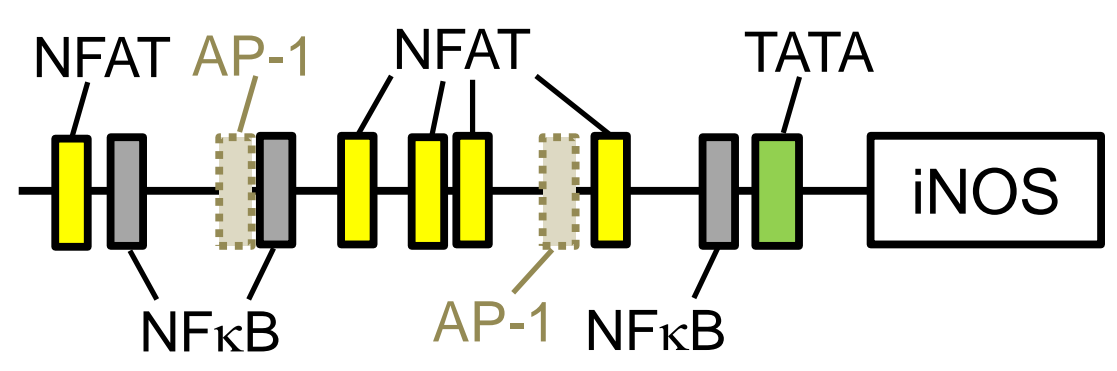

C

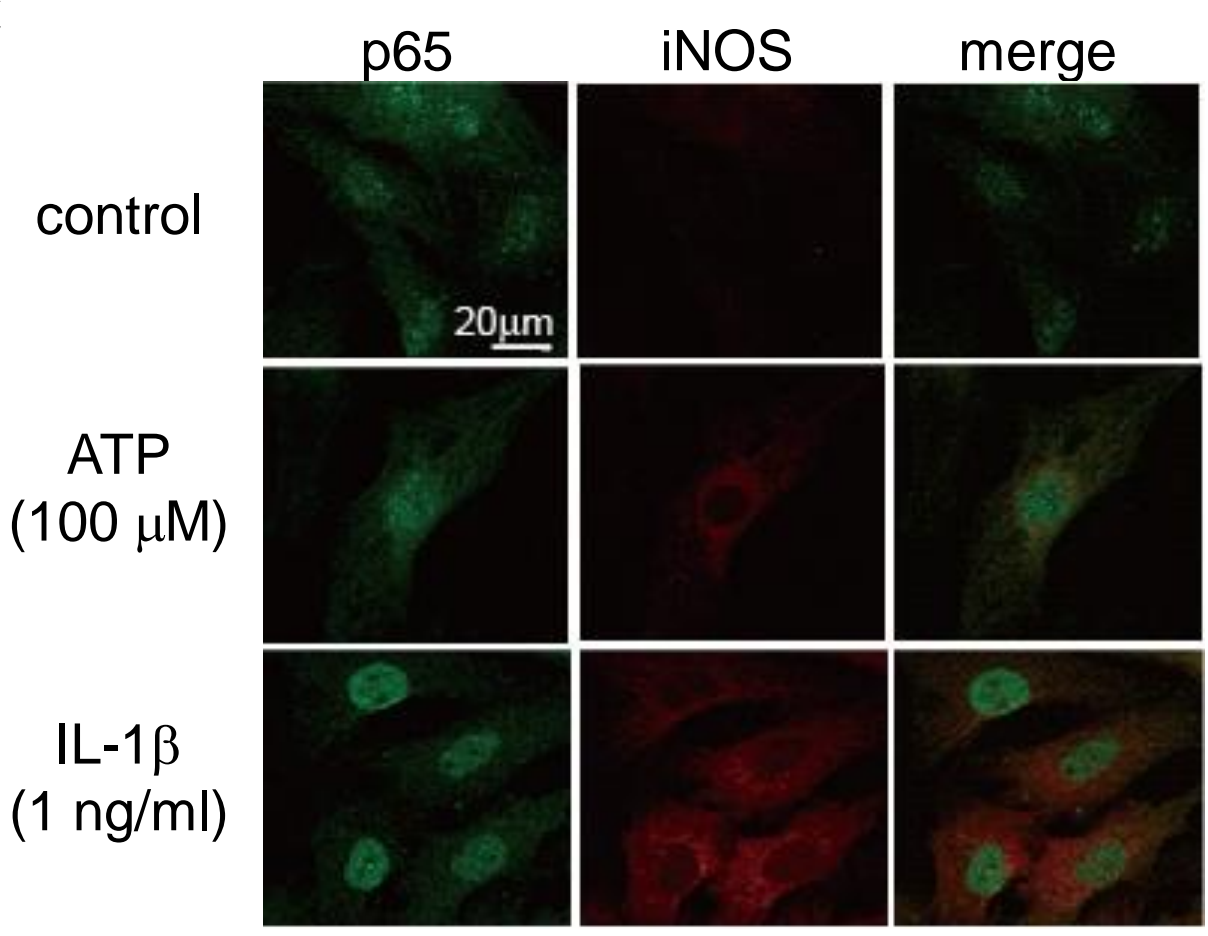

D

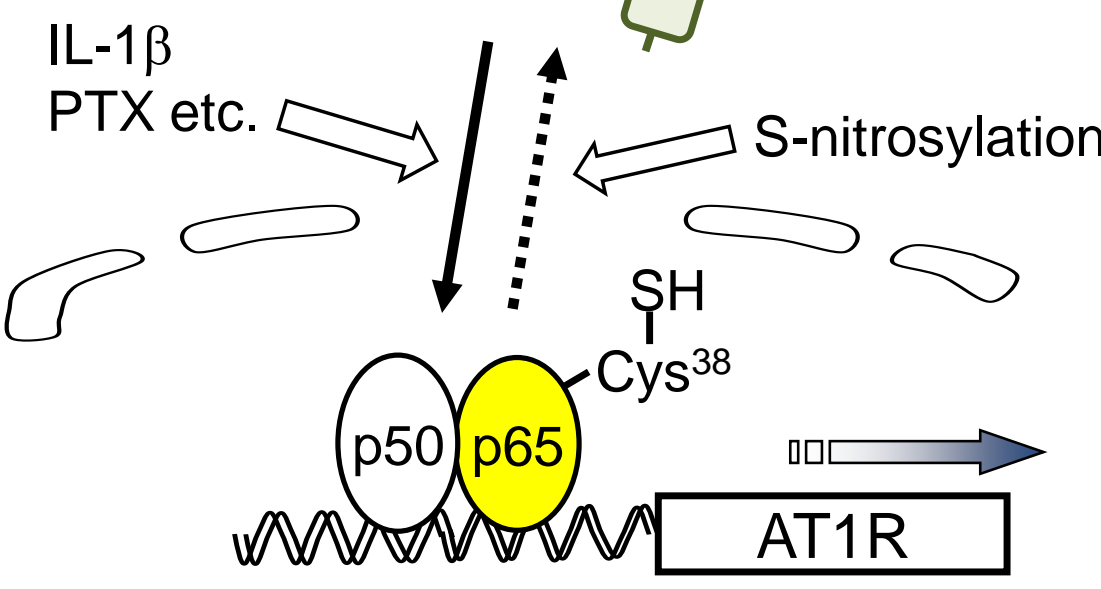

Figure 4. Nishida et al. 